\title{
The importance of hydrothermal venting to water-column secondary production in the northeast Pacific
}

\author{
Brenda J. Burd ${ }^{\mathrm{a}^{*}}$ and Richard E. Thomson ${ }^{\mathrm{b}}$ \\ * Corresponding author
}

a Ecostat Research Ltd, 1040 Clayton Rd. North Saanich, BC Canada V8L 5P6;

bburd@telus.net; 250-655-1017

${ }^{\text {b }}$ Fisheries and Oceans Canada, Institute of Ocean Sciences, PO Box 6000 Sidney, BC

Canada V8L 4B2 


\section{ABSTRACT}

The purpose of this study is to show that seafloor hydrothermal venting in the open northeast Pacific Ocean has a marked impact on secondary biomass and production within the overlying water column. Specifically, we use net tows and concurrently measured acoustic backscatter data collected over six summers to examine the effects of hydrothermal venting from the Endeavour Segment of Juan de Fuca Ridge on macro-zooplankton biomass and production throughout the entire $2000 \mathrm{~m}$ depth range. Previous research shows that ontogenetic diapausing migrators and their predators from the upper ocean aggregate above the neutrally buoyant plumes in summer and resume feeding on plume and bottom upwelled particles, resulting in increased zooplankton reproductive output to the upper ocean. Within the limitations of our sampling methodology, net tows reveal a statistically significant exponential decline in total water-column biomass with increasing lateral distance from the vent fields. The acoustic backscatter data show a similar decline, but only below $800 \mathrm{~m}$ depth. Near-surface biomass was highly variable throughout the region, but values near vents consistently ranged higher than summer values found elsewhere in the offshore northeast Pacific. Water-column biomass was similar in magnitude above and below $800 \mathrm{~m}$ depth throughout the region. Because epiplume biomass can be advected a considerable distance from vent fields, biomass enhancement of the water column from hydrothermal venting may extend considerable distances to the west and northwest of the vent sites, in the prevailing directions of the subsurface flow. Based on the extensive acoustic Doppler current profiler (ADCP) data collected, and the strong correlation between zooplankton production derived from net sample biomass and acoustic backscatter intensity, we estimate that daily macro-zooplankton production in the upper $400 \mathrm{~m}$ of the water column within $10 \mathrm{~km}$ of the vent fields averages approximately $16 \%$ of photosynthetic primary production (the "Z ratio"), whereas the total watercolumn zooplankton production averages $26 \%$ of surface primary production. Local grazing-rate 
estimates, metabolic constraints and other open-ocean studies suggest that the $\mathrm{Z}$ ratio should be no higher than $5 \%$, which it is at off-axis background sites in the study region. This finding indicates that nutrient sources other than upper-ocean primary production fuel both upper- and deep-ocean zooplankton biomass and growth near the Endeavour Ridge hydrothermal vents.

\section{Keywords}

Endeavour Ridge, hydrothermal vents, zooplankton production and biomass, fin whales 


\section{Introduction}

Although the importance of zooplankton productivity to ecosystem dynamics in the upper ocean has been discussed by numerous authors, the contribution of deeper ocean productivity is generally considered insignificant, and therefore mainly ignored. Most studies of heterotrophic biomass or production patterns in the open ocean focus almost exclusively on the top $250 \mathrm{~m}$ of the water column (Sabates et al., 1989; Gili, 1989; Brodeur and Ware, 1992; Mackas, 1995; Brodeur et al., 1996; Young et al., 1996; Sugimoto and Tadokoro, 1997; Goldblatt et al., 1999; Nagasawa, 2000a, b; Uye et al., 2000; Stock and Dunne, 2010; Fukuda et al., 2012; Huo et al., 2012). Much of this research is based on the assumption that virtually all heterotrophic production in the open ocean is derived from top-down nutrient input and, therefore, only the organisms which are migrating above thermocline depth have direct access to nutrition from primary producers. It then follows that the bulk of secondary productivity in the open ocean must be occurring in the ocean layer overlying the main and seasonal thermoclines.

Permanent biological scattering layers are observed below the thermocline throughout the northeast Pacific (cf. Hazen and Johnston, 2010). It is generally assumed that the zooplankton constituting these deeper (400-800 m) layers are dependent either on a surface rain of fecal pellets and detritus, or that the animals migrate diurnally to the ocean surface to feed. Zooplankton in these layers are often referred to as meso-pelagic producers, although they are usually ignored in production studies unless they are collected during diel migration to the upper ocean. Well-documented enhanced zooplankton layers are also found overlying the spreading vent plumes at 1900-2100 m depth at the Endeavour Segment of Juan de Fuca Ridge located 300 km off the British Columbia-Washington coast (Thomson et al., 1989; Burd et al., 1992; Burd and Thomson, 1994, 1995, 2012). The laterally spreading, neutrally buoyant hydrothermal plumes provide an extraordinary food source for epiplume zooplankton (aggregations of upper 
water column and deep zooplankton species found just above the spreading, neutrally buoyant plumes), as evidenced by stable isotope analyses from net-tow samples (Burd et al., 2002).

In this paper, we revisit our earlier findings (Burd and Thomson, 1994, 2000), which report that hydrothermal venting appears to increase macro-zooplankton and jellyfish biomass (organisms collected in $>0.333 \mathrm{~mm}$ mesh nets) throughout the entire water column. Our new findings are based on a much broader temporal and spatial set of net samples and concurrent acoustic backscatter data. The net samples are considered the most reliable for calculating total water column biomass and production as the nets are towed continuously upward from nearbottom depths and are supported by accurate flow volume estimates derived from coincident current velocity measurements (Burd and Thomson, 1993). However, net sampling has limitations in that it integrates biomass over a broad depth range, a range that has varied over the years as a result of different sampling and research requirements. Recently, Burd and Thomson (2012) have shown that modelled backscatter from a $150 \mathrm{kHz}$ ADCP towed concurrently with nets provides a highly predictable estimate of total net biomass. Because of the near continuous nature of the acoustic signal, the acoustic backscatter record can be used to focus on specific depth layers and biomass features a-posteriori. Here, we combine both sources of data to determine how the vent fields may be affecting secondary meso-zooplankton biomass and production in the northeast Pacific.

The epiplume fauna are a mixture of highly diverse deep-sea fauna, along with mesopelagic ontogenetic migrators (particularly Neocalanus spp.) and their predators, all of which were once thought to be restricted to maximum depths of 800-900 m (the depth of the oxygen minimum) during their diapause phase in the northeast Pacific (Miller et al., 1984; Batchelder, 1985; Terazaki and Miller, 1986; Landry and Fagerness, 1988; and Miller and Clemons, 1988). Our observations also show that these migrators are extremely rare below 1000 
m outside the general region of the Endeavour Ridge vent fields (Burd and Thomson, 1994, 1995). However, more recent deep-sea net studies have shown that a few of these copepod species can be found in diapause to depths of upwards of $2000 \mathrm{~m}$ in the Pacific Ocean (Kobari and Ikeda, 2001a,b).

Diapausing migrators in the Endeavour Ridge venting region congregate above the plumes (Burd and Thomson, 1995) and resume feeding (Burd et al., 2002), thus increasing their reproductive output as evidenced by the enhanced concentration and diagnostic composition of lipids in ascending particles relative to background areas (Cowen et al., 2001; Wakeham et al., 2001). Acoustic backscatter patterns obtained from towed ADCPs, combined with a simple circulation model, suggested that non-diurnal vertical migrations were occurring between the deep epiplume layer and the upper ocean (Burd and Thomson, 1994; Burd et al., 2002) and that round-trip migrations were possible without the animals being advected beyond the range of the detectable hydrothermal effluent (see also Thomson et al., 2009).

Because buoyant plumes at Endeavour Ridge rise only to a depth of about $1700 \mathrm{~m}$, deepsea hydrothermal venting cannot directly affect surface phytoplankton production in the vicinity of the vent fields. Moreover, the region is part of the high nutrient northeast Pacific circulation system and is therefore not expected to have elevated phytoplankton productivity (Wong et al., 1995). Only during exceptionally rare events, such as a major volcanic eruption in the Aleutian Islands, can the addition of iron possibly lead to enhanced surface productivity in sectors of the northeast Pacific (Hamme et al., 2010). In contrast, the additional nutrients provided by the spreading hydrothermal plumes near the seafloor and the enhanced secondary production from epiplume zooplankton are expected to increase heterotrophic production in the region. Wilcock et al. (2012) also discuss the possibility that open-ocean whale feeding patterns may be influenced by the proximity of hydrothermal venting. The animals living in the vicinity of Endeavour Ridge 
- ranging from macro-zooplankton to jellyfish to various deep-sea species of fish and possibly

Fin and Blue Whales (Wilcock et al., 2012; Soule and Wilcock, 2013) - may be taking advantage of enhanced production of larger zooplankton in the upper ocean that is ultimately fuelled by trophic redistribution of extraordinary primary production originating with the hydrothermal vent plumes. Feeding by large marine mammals has been documented to $800 \mathrm{~m}$ in the open ocean (Hazen and Johnston, 2010). What is currently unknown is whether hydrothermal venting could be contributing to increased biomass or secondary production in the overlying upper ocean where these larger animals are feeding.

\section{Methods}

\subsection{The towed sampler}

In June and July of 1991-1996, we collected 197 net samples from 33 tows undertaken at various hours of the day within $200 \mathrm{~km}$ of four of the five primary identified Endeavour Ridge vent fields (Salty Dawg, High Rise, Main Endeavour and Mothra) located at $2200 \mathrm{~m}$ depth at $47^{\circ} 57^{\prime} \mathrm{N}, 129^{\circ} 06^{\prime} \mathrm{W}$ in the northeast Pacific (Thomson et al., 2005). Figure 1 shows the locations of all net tows used in this study, and Figure 2 exhibits the tow apparatus configuration. Supplemental Table A includes geo-referenced depth ranges and the time of day for all nets and tows. Data obtained during the net tows include: the sampling time, the locations and depth ranges of the tows, faunal counts, identity of all fauna to lowest taxonomic level, stage, sex, length and width measurements, and the mean dry-weight biomass of each organism. Net samples also had detailed ( $1 \mathrm{~m}$ resolution) in situ temperature and salinity profile data to aid in identifying hydrographic layers of interest in the water column. Burd and Thomson (1994) describe the methods for counting, determining sex, developmental stage, length, width, and mean dry-weight biomass measurements for each organism. The attitude sensors and three- 
dimensional current measuring capabilities of the ADCP (see below) enabled us to determine the flow volume through each net to within a small 2 to $3 \%$ error (Burd and Thomson, 1993).

A $153 \mathrm{kHz}$ RDI ADCP with four downward-looking transducer heads was mounted just below a Guildline Conductivity-Temperature-Depth (CTD), a Seatech transmissometer, and a 7net apparatus with $330 \mu \mathrm{m}$ mesh and $1-\mathrm{m}^{2}$ opening at the mouth (Fig. 2). The use of a multipleconductor tow cable allowed us to monitor the data from the ADCP-CTD-transmissometer package in real time, and to open and close each net electronically from onboard the research ship. The entire system was towed at an angle through the water column (Burd and Thomson, 1993, 1994). Thomson et al. (1991, 1992) describe the acoustic backscatter measurements, background calibration and use of other instrumentation.

\subsection{Water-column biomass}

Six of the seven nets on the multi-instrumented ADCP-CTD-optical apparatus were towed in succession from near-bottom to the surface with one net towing continuously from surface to bottom. Data from the surface-to-bottom net are not used. The total water column biomass was estimated by calculating the mean biomass per $\mathrm{m}^{3}$ for each net, and multiplying the biomass for the net by the depth range spanned by that net. We then summed the individual biomass estimates for each net to obtain the total biomass for the water column for each particular tow. Because vertical tows had variable maximum sampling depths, total biomass values were standardized to a maximum depth of $2000 \mathrm{~m}$ for all samples, based on the mean biomass per $\mathrm{m}^{3}$ for each tow. This standardization is acceptable since our observations consistently show that there is typically very little biomass below $2000 \mathrm{~m}$ depth at any location. To determine the contribution of each faunal type to the overall biomass in each net, net biomass was separated 
into major taxonomic groups. The relationship of faunal group biomass to total net biomass was examined using least-squares linear regression.

The methodology for estimating the biomass using the first ADCP acoustic bin (the bin spanning the first 4-8 $\mathrm{m}$ depth range immediately below the net system) is described in Burd and Thomson (2012). This method was used to estimate water-column biomass from each $30 \mathrm{~s}$ sampling interval of the ADCP, with estimates of resulting biomass weighted by the volume of water flowing past the instrument during that period (Burd and Thomson, 1993). Total watercolumn biomass was then estimated as an average for both down- and up-casts of the instrument package for depth intervals of interest relative to scattering layers and expected production in the water column, which we have designated for the following depth ranges: (1) 0-150 m, corresponding to the surface primary production layer; (2) 150-400 m, the upper ocean migratory range; (3) 400-800 m, the mesopelagic layer (some migrators, many permanent); (4) 800-1600 m, the typically uniform, low-biomass layer; and (5) 1600-2000 m, coinciding with the epiplume scattering layer, when present.

Water-column biomass estimates were integrated and standardized over the same depth range $(0-2000 \mathrm{~m})$ for both nets and ADCP backscatter data sets. Our estimate for the "distance from the vents" corresponds to the mean lateral distance in kilometers from the up-cast portion of a given tow to the four main vent fields in the axial valley (Thomson et al., 2005). One of the tows was from the Explorer Ridge venting region (Tunnicliffe et al., 1986) located roughly 80 $\mathrm{km}$ to the northeast of Endeavour Ridge, and two tows were from the Co-axial Seamount region (Baker et al., 1995; Tunnicliffe et al., 1997) located $125 \mathrm{~km}$ to the south of Endeavour Ridge. These distant tows were also considered to be near-vent samples, with distance measured from the nearby venting sources. 


\subsection{Secondary zooplankton (consumers and predators) production estimates}

Huo et al. (2012) have reviewed the methods for estimating production for open-ocean zooplankton. The authors recommend conversion of zooplankton biomass from nets to secondary production values following Ikeda and Motodo (1978), whose method is suitable over a broad range of zooplankton groups, whereas other methods tend to be focused on copepods. The method utilizes size-distributed biomass and ambient temperature by first calculating zooplankton respiration rate, $\mathrm{R}_{\mathrm{o} 2}(\mu \mathrm{L} \mathrm{O}$ per animal per hour), based on the biomass for each organism and the mean ambient-water temperature, $\mathrm{T}\left({ }^{\circ} \mathrm{C}\right)$, in the sampling depth range. Specifically, we used

$$
\mathrm{R}_{\mathrm{o} 2}=-0.2312+0.7886 \cdot \ln (\mathrm{W})+0.0490 \cdot \mathrm{T},
$$

where $\mathrm{W}$ is the mean dry wt biomass (in $\mathrm{mg}$ ) for each taxon in each sample. Here, $\mathrm{T}$ is determined from the high-resolution water-property data collected by the CTD during each net tow. We also calculated respiration for a range of sizes within species for which this relationship was relevant. The respiration was then transformed to carbon units (mg C/animal/hr) assuming a respiration quotient of 0.8 (cf. Runge and Roff, 2000), where

$$
\operatorname{Rc}(\text { respiration in } \mathrm{mg} \mathrm{C})=\mathrm{R}_{\mathrm{o} 2} \cdot 0.8 \cdot(12 / 1000) \cdot 22.3
$$

in which 12 is the molar mass of $\mathrm{C}$ in $\mathrm{g} / \mathrm{mol}$, and 22.3 is the molar volume of oxygen in $\mathrm{L} / \mathrm{mol}$. If gross growth-efficiency and assimilation-efficiency are assumed to be 0.3 and 0.7 (as proposed by Runge and Roff, 2000), we can calculate the production P (in mg C/animal/hr) as:

$$
\mathrm{P}=30 \cdot \mathrm{Rc} /(70-30)=0.75 \cdot \mathrm{Rc}
$$

(cf. Ikeda and Motoda, 1978). The production obtained for each taxon using (3) was then

converted to a depth-weighted production per $\mathrm{m}^{3}$ for each net and standardized to total production for the 0-2000 $\mathrm{m}$ depth range (as for dry weight biomass described above). Total 
zooplankton production for the water column is therefore the summed production for all taxa over the $2000 \mathrm{~m}$ depth range.

\section{Results}

\subsection{Zooplankton Biomass}

As indicated by the least-squares regression estimates in Figure 3a, towed net biomass integrated over the 0-2000 $\mathrm{m}$ depth range (calculated as total biomass in a $1 \mathrm{~m}^{2}$ surface area column from the surface to a depth of $2000 \mathrm{~m}$, corresponding to biomass per $2000 \mathrm{~m}^{3}$ ) showed a significant exponential decline with distance from the main vent fields. For the log-transformed data, we find $\mathrm{r}^{2}=0.36(\mathrm{p}<0.01)$, where $\mathrm{r}$ is the Pearson coefficient of correlation. Biomass estimates from net samples indicate that total water column meso-zooplankton biomass (surface to $2000 \mathrm{~m}$ depth) ranged from about 8 to $41 \times 10^{3} \mathrm{mg} \mathrm{DW} \mathrm{wt} / 2000 \mathrm{~m}^{3}$.

Table 1 shows the mean, standard deviation (SD) and Pearson correlation for proportion of total dry-weight biomass for each net of copepods, chaetognaths, euphausiids, other crustaceans, gelatinous organisms, fish and miscellaneous taxa. The proportion of total biomass that can be attributed to copepods, chaetognaths, other crustacea, and euphausiids was most reliably determined $(\mathrm{p}<0.01)$ from the total biomass, followed by that for fish $(\mathrm{p}<0.05)$. The biomass of the remaining, rarer miscellaneous fauna and gelatinous organisms, was not a consistent proportion $(\mathrm{p}>0.05)$ of total net biomass (Fig. 4). Copepods made up the majority of net biomass $(43 \% \pm 15 \% \mathrm{SD})$, followed by chaetognaths $(16 \% \pm 11 \%)$, other crustacea $(12 \% \pm 8 \%)$ and gelatinous fauna $(15 \% \pm 13 \%)$. Fish, euphausiids and the miscellaneous taxa were least important in terms of biomass.

Total water-column biomass estimates derived from the net tows and from the ADCP backscatter records have relatively similar ranges (Figs. 3 and 5). Integrated water-column 
biomass from 0-2000 m depth (biomass in a $1 \mathrm{~m}^{2}$ column of water $2000 \mathrm{~m}$ deep), based on the ADCP backscatter model of Burd and Thomson (2012), ranged from 9-35 dry weight $\mathrm{g} / \mathrm{m}^{2}$, and showed a decline with distance from the vent fields (Fig. 5), although the relationship was too variable to be statistically significant $(\mathrm{p}>0.05)$. When the biomass estimates based on the ADCP backscatter data are split into depth ranges (i.e., five separate data sets, as shown in Fig. 5), the following patterns become evident:

(1) There was a decreasing trend in biomass with distance from the four main vent fields for all depth ranges; however, only the data sets for the bottom two depth ranges (800-1600 $\mathrm{m}$ and 1600-2000 m) showed significant relationships between integrated biomass (g dry weight per $\left.2000 \mathrm{~m}^{3}\right)$ and distance from vent fields $\left(\mathrm{r}^{2}=0.11, \mathrm{p}<0.04\right.$ and $\mathrm{r}^{2}=0.33, \mathrm{p}<0.01$, respectively); (2) The surface layer (0-150 m depth) has the most spatially variable biomass distribution, and this distribution appears to be unrelated to distance from the vent fields;

(3) The proportion of total water-column biomass is relatively high for depth ranges 1,2 and 4 (0-150, 150-400, and 800-1600 m, respectively), somewhat lower for depth range 3 (400-800 m), and lowest for depth range $5(1600-2000 \mathrm{~m})$;

(4) The water-column biomass from the surface to $800 \mathrm{~m}$ depth was roughly equal to that from $2000 \mathrm{~m}$ upward to $800 \mathrm{~m}$ depth for all tow locations and dates in the study.

\subsection{Zooplankton Production}

As with biomass, the net-derived zooplankton production integrated over the $0-2000 \mathrm{~m}$ depth range showed a significant exponential decline with distance from the main vent fields (Fig. 3b; for the log-transformed data, $\mathrm{r}^{2}=0.15, \mathrm{p}=0.01$ ). Total water-column production ranged from 30 to $220 \mathrm{mg} \mathrm{C} / \mathrm{m}^{2} /$ day, with highest production values near the vents. Production from nets was pro-rated based on the $0-150 \mathrm{~m}$ depth fraction of the total zooplankton production values for 
the shallowest net (net 7) in all tows. Because these nets were typically towed from $400 \mathrm{~m}$ to surface, and occasionally from $800 \mathrm{~m}$ to surface, and because most of the biomass in the upper ocean tends to be concentrated near the surface, the resulting analysis yields a highly conservative zooplankton production estimate of 4-28 $\mathrm{mg} \mathrm{C} / \mathrm{m}^{2} /$ day from nets for the top $150 \mathrm{~m}$ of the water column, with an average of $16 \mathrm{mg} \mathrm{C} / \mathrm{m}^{2} /$ day for tows within $10 \mathrm{~km}$ of vents.

The log-log function in Figure 6 reveals an exponential relationship between mean biomass $\left(\mathrm{g} / \mathrm{m}^{3}\right)$ and mean production $\left(\mathrm{mg} \mathrm{C} / \mathrm{m}^{3} /\right.$ day) for the towed net samples. For ease of visualization, the figure shows summed values for each tow. However, regression analyses were actually conducted on individual net samples $(\mathrm{N}=197)$. In log-log coordinates, we find that for a given sample net production equals $0.0041 \times(\text { net sample biomass })^{1.0021}$, with an adjusted $r^{2}=0.85$ $(\mathrm{p}<0.01)$. By extrapolating this relationship to the biomass estimated from the ADCP backscatter intensity within the upper $150 \mathrm{~m}$ of the water column, we find that near-surface production based on backscatter ranged from 8 to $55 \mathrm{mg} \mathrm{C} / \mathrm{m}^{2} /$ day, with an average value of 25 $\mathrm{mg} \mathrm{C} / \mathrm{m}^{2} /$ day for tows within $10 \mathrm{~km}$ of vent fields. The upper ocean production values derived from the ADCP backscatter data are likely more appropriate than those derived from the net data since we used only backscatter values from $150 \mathrm{~m}$ to the surface in the summations, thus taking into account the typical concentration of zooplankton biomass in the near surface layer.

\section{Discussion}

Our findings support a previous, more limited study (Burd and Thomson 1994), which finds that water-column zooplankton biomass increases near hydrothermal vent fields at Endeavour Ridge. Results of the current study reveal a complex pattern of decreasing vertically integrated water-column zooplankton biomass and zooplankton production with lateral distance from the main venting sites on the ridge. This relationship, with a spatial extent limited by the 
coverage of our datasets, applies to an approximate distance of $200 \mathrm{~km}$ from the venting regions and is particularly well defined for biomass below $800 \mathrm{~m}$ depth. A major factor contributing to the complexity of the observed biomass distribution is the linearly distributed structure of the Endeavour Ridge venting sources; the venting is not localized but consists of four primary sites spaced roughly $2 \mathrm{~km}$ apart in a northeastward direction along the axial valley. In addition, the different attributes and chemistry of individual vent plumes have differing effects on the biomass distributions over the $15 \mathrm{~km}$ length of the axial valley (Kelley et al., 2012; Lavelle et al., 2013). Variations in the tidal and non-tidal (residual) currents also affect the drift of the plumes, which are especially variable over the ridge where topographic factors are most pronounced (Thomson et al., 1990, 2005, 2009). Spatial and temporal variations in the plumes are also expected to affect the distribution of opportunistic epiplume organisms in the deep scattering layer overlying the vent fields. These variations also contribute to considerable temporal variability in the depths and horizontal positions of the deep scattering layers (Burd and Thomson, 2012).

Currents within the axial valley are constrained in the along-axis direction and are strongly sheared in the horizontal directions due to the effects of the ridge topography and venting-induced flows (Thomson et al., 2003, 2005, 2009; Lavelle et al., 2013). Deep circulation above the axial ridge is generally to the west, as shown by the presence of vent-plume signatures found $>10 \mathrm{~km}$ to the west of ridge axis (Burd and Thomson, 1994). In the present study, the two tows taken about $70 \mathrm{~km}$ to the northwest of the main vent fields had unusually high water-column biomass, with evidence of a remnant scattering layer at the depth of the spreading plume (Burd and Thomson, 1994). These findings suggest that the epiplume biomass can drift a considerable distance from the ridge axis. Observations of upward fluxes of lipid-rich organic particles near the ridge are high, both within the axial valley and $3 \mathrm{~km}$ to the west of the valley, and lowest several kilometers to the east of the valley (Cowen et al., 2001). These observations further 
indicate that biomass enhancement of the water column from hydrothermal venting at Endeavour Ridge may occur at considerable distance to the west and northwest of the vent fields. Although we have insufficient net-tow data to determine long-term changes in biomass, such as those described in strictly upper-ocean zooplankton studies in the northeast Pacific (Mackas and Beaugrand, 2010), it is likely that physical and biological processes are contributing to interannual variability in our data sets.

\subsection{Faunal Groups}

Copepods and other crustaceans, along with chaetognaths, together comprise about $72 \%$ of the total observed zooplankton biomass, with relative proportions of total biomass from these dominant groups remarkably consistent over space and time, as well as with the depth of the net samples (Table 1; see also Atkinson et al., 2012). This consistency in dominant faunal group biomass composition is likely the reason for the close regressional relationship between dryweight biomass and production for the net samples (Fig. 6), which allowed us to derive depthspecific production from biomass estimates for the ADCP backscatter data. These consistent faunal groupings appear to comprise the basic macro-zooplanktonic structure of the food chain throughout the water column of the northeast Pacific in the vicinity of Endeavour Ridge.

Copepods alone make up the largest component (mean of 43\%) of total biomass in our net samples. This is consistent with other ocean studies such as Atkinson et al. (2012) who found that copepods constitute as much as $75 \%$ of the Southern Ocean meso-zooplankton in the upper-ocean layer. The large copepod contribution throughout the water column is also consistent with the fact that our sampling was undertaken over six summers, with survey periods ranging from June through August when ontogenetic-depth migrations occur in the major copepod taxa (Mackas et al., 1993). 
Over the six summers of observations, there were spatially and temporally patchy aggregations of salps, gooseneck barnacles and euphausiids in the surface waters. Estimates of biomass and production for euphausiids are less consistent than for the aforementioned groups, probably because euphausiids can form patchy, seasonal surface swarms. For example, the nearsurface nets from two tows in 1992 had the highest proportion of biomass (19-24\%) from the euphausiid Thysannoesa of any tows in any year. This taxon is a swarmer (Atkinson, 2012), which can proliferate and drift in dense patches under the right environmental conditions. It is likely that seasonal patchiness in surface swarmers is most responsible for our observation that near-surface zooplankton biomass and production have the weakest functional relationship with distance from the vents than for any other depth range. This, in turn, affected our estimates of total water-column biomass.

The proportion of biomass from gelatinous organisms varies considerably among the net samples. Burd and Thomson (2000) have discussed the occurrence of unusual biomass of gelatinous organisms near vents and the occurrence of seasonal "blooms" in near-surface waters, as well as deeper layers. In 1995 and 1996, we noted surface blooms of gelatinous salps, which are poor sound scatterers (Stanton et al., 1994; Bierley et al., 2005) and are, therefore, particularly difficult to distinguish using the single-frequency acoustic measurement system used in the present study (see Burd and Thomson, 2012). Burd and Thomson (2012) have described other possible estimation errors related to the use of the ADCP in near-surface oceanic layers.

\subsection{Deep-ocean biomass and productivity}

Both the towed net data and values estimated from the ADCP backscatter records clearly show that below $800 \mathrm{~m}$, zooplankton biomass and production were significantly higher near the vent fields than at off-axis sites, indicating that deeper ocean biomass and productivity are 
enhanced by hydrothermal venting. The fact that the summed water-column biomass is similar above and below $800 \mathrm{~m}$ depth throughout the region means that the deep-water biomass is likely important in nutrient cycling in the water column in the summer, a time when the typical mesozooplankton found above the spreading hydrothermal plume release their reproductive byproducts (eggs and larvae) to float to the surface (Burd and Thomson, 1995). Upward fluxes of organic particulates are higher near the Endeavour Ridge vents than off-axis (Cowen et al., 2001) particularly in spring, with lipids analyses showing that the increased upward flux near the ridge is dominated by zooplankton lipid signatures (Wakeham et al., 2001). Burd and Thomson (1994) describe a circulation model and empirical evidence from towed ADCPs suggesting considerable vertical migration throughout the summer in the larger copepods and their predators. We have not found any other studies that examine zooplankton productivity in the Pacific Ocean at depths greater than $250 \mathrm{~m}$.

In the absence of year-round water-column biomass measurements, it is impossible to determine the extent to which this deep-water biomass enrichment affects annual production cycles in the vicinity of the ridge. Long-term deep acoustic moorings suggest that the deep scattering layers associated with the Endeavour Ridge vent plumes may be minimal in the summer months and more intense in spring and fall (Thomson, unpublished data). Therefore, it is possible that the epiplume biomass is an important year-round contributor to water-column production.

\subsection{Upper-ocean Biomass and Productivity}

As discussed above, shifts in seasonal development cycles, diel migration of dominant taxa, seasonal blooms of certain taxa, and related hydrographic conditions result in highly variable near-surface biomass and production estimates in the open ocean (Atkinson et al., 2012). 
Previous studies of zooplankton biomass and production have typically focused on the upper 250 m of the water column, which can miss a considerable proportion of zooplankton and, therefore, organic cycling in the water column from diel migrators (Madin et al., 2001) as well as from previously described ontogenetic migrators such as the dominant Neocalanus spp. and associated predators (Burd et al., 1992, 1994; also Atkinson et al., 2012). Biomass values from the present study have been compared with literature values derived from other studies, with emphasis on the northeast Pacific in summer (Table 2). Near-surface (0-150 m depth) values herein are consistent with other studies but, with the exception of near-coastal areas, ranged considerably higher near the venting region than for near-surface values found at other open-ocean regions. Background biomass values in the present study, particularly those obtained several hundred kilometers to the east of the Endeavour vent fields in Cascadia Basin, were considerably lower than values near the vents, and similar to those expected elsewhere in the open northeast Pacific (Table 2; see Thomson et al., 1995 for water properties and hydrothermal venting in Cascadia Basin). Although it is difficult to compare production estimates for studies using different methodologies, estimated zooplankton production values of $8-55 \mathrm{mg} \mathrm{C} / \mathrm{m}^{2} /$ day for macrozooplankton in the top $150 \mathrm{~m}$ (based on ADCP backscatter data) for the region of Endeavour Ridge appear to be similar to, or higher than, values found at similar depths at offshore stations in the warmer Japan Sea (Ikedo and Motada, 1978; Uye et al., 2000). Although macro-zooplankton production rates in the top $150 \mathrm{~m}$ of the water column near Endeavour Ridge are similar to values obtained by Huo et al. (2012), their findings indicate that considerable secondary production from micro-zooplankton may have been missed in our study, which measured only the zooplankton captured in $0.333 \mathrm{~mm}$ mesh nets. Specifically, Huo et al. (2012) concluded that $57-84 \%$ of secondary production in the Yellow Sea is from the micro-grazers. 
Stock and Dunne (2010) review global ratios of meso-zooplankton production to primary production ("Z ratios") in the open ocean, concluding that the $\mathrm{Z}$ ratio is likely between 0.02 and 0.1 in the modest primary production, cold-water conditions found in the northeast Pacific. Uye et al. (2000) found similar results ( $\mathrm{Z}$ ratio $~ 0.75$ for all meso-zooplankton) for the northwest Pacific Ocean off coastal Japan. Calbet (2001) estimated that mezo-zooplankton remove or ingest on average $12 \%$ of primary-production biomass in the open global ocean. Dagg (1993) also found that the dominant grazing copepods in the northeast subarctic Pacific (our region of study) consume only $6-15 \%$ of spring phytoplankton biomass on a daily basis. Assuming that zooplankton can utilize about $30 \%$ of ingested biomass for growth (Atkinson et al., 2012), yields a $\mathrm{Z}$ ratio $<0.5$, which is reasonable in the present study.

Although surface primary production has not been measured specifically at Endeavour Ridge in the years of this study, there are several sources that provide a likely range of values. A remote (satellite) sensing model by Platt and Sathyendranath (1988) applied to SEAWIFS data (http://seawifs.gsfc.nasa.gov/SEAWIFS.html) suggests that depth-integrated summer primary productivity off Vancouver Island at the longitude of Endeavour Ridge in July and August is between 500-700 $\mathrm{mg} \mathrm{C} / \mathrm{m}^{2} /$ day. However, it is recognized that in situ verification is lacking for water-column conditions locally. More direct open ocean productivity measurements using the "clean" $\mathrm{C}_{14}$ uptake method in the open northeast Pacific are around $350 \mathrm{mg} \mathrm{C} / \mathrm{m}^{2} /$ day (Martin et al., 1987), whereas Wong et al. (1995) found near surface primary production at Ocean Station "P" in the central northeast Pacific to have a maximum of $466 \mathrm{mg} \mathrm{C} / \mathrm{m}^{2} /$ day in summer between 1984-1990, with an average $140 \mathrm{mg} \mathrm{C} / \mathrm{m}^{2} /$ day throughout the year. Their closest temporal data (July 1988) to the present study yielded an average of $~ 350 \mathrm{mg} \mathrm{C} / \mathrm{m}^{2} /$ day at Ocean Station "P". Harrison et al. (1999) and Boyd and Harrison (1999) describe seasonal primary productivity of 300-600 mg C/m²/day (offshore-coastal) in the northeast subarctic Pacific near Line "P" station 
12 (see also Whitney and Freeland, 1999), which is closest to the longitude of Endeavour Ridge. However, all of these estimates assume a standardized mixed-layer depth in summer of $40 \mathrm{~m}$. In actuality, the summer mixed-layer depth is known to be highly variable on short time scales and over a 50-year period of observations is found to have a mean of roughly $20 \mathrm{~m}$ in July and August in much of the northeast subarctic Pacific (Thomson and Fine, 2009). This shallower mixed-layer depth would produce a considerably lower primary productivity estimate for the upper ocean. Hamme et al. (2010) also showed that summer surface chlorophyll-a values tend to be lower at Line "P" stations close to Endeavour Ridge than at Ocean Station "P", partly due to nitrate depletion in summer (Whitney and Freeland, 1999). Finally, primary production in the northeast Pacific appears to have declined in the 1990s compared to the 1970s and 1980s (Whitney and Freeland, 1999), a trend which is thought to be related to sea-surface warming (Mackas et al., 2007). With these variables in mind, and taking the various estimates of surface primary production for the region into account, we obtain a conservative estimate of mean surface primary production of $350 \mathrm{mg} \mathrm{C} / \mathrm{m}^{2} /$ day in the vicinity of Endeavour Ridge over the many summer seasons examined in this study.

Our results suggest that for all surface nets ( 400 m to surface) towed within $15 \mathrm{~km}$ of the vent fields, meso-zooplankton production averaged $55 \mathrm{mg} \mathrm{C} / \mathrm{m}^{2} /$ day, with a maximum of $138 \mathrm{mg}$ $\mathrm{C} / \mathrm{m}^{2} /$ day, resulting in average and maximum $\mathrm{Z}$ ratios of 0.16 and 0.39 , respectively, with the latter probably occurring at times of episodic iron inputs (Harrison et al., 1999). These higher than expected $\mathrm{Z}$ ratios do not take into account the considerable zooplankton production found below $400 \mathrm{~m}$ depth in this study, which in total for the depth range $0-2000 \mathrm{~m}$ is closer to $91 \mathrm{mg}$ $\mathrm{C} / \mathrm{m}^{2} /$ day (see also Steinberg et al., 2000). The dominant zooplankton grazers in this region of the northeast Pacific (and, in particular the Endeavour Ridge region; cf. Burd and Thomson, 1992) have been shown to consume only 6-15\% of primary production during peak spring 
conditions (Dagg, 1993: http://dx.doi.org/10.1016/0079-6611(93)90012-3). If we assume a growth efficiency of about 30\% (Atkinson et al., 2012), then the Endeavour Ridge summer productivity should only be able to support $\sim 20 \mathrm{mg} \mathrm{C} / \mathrm{m}^{2} /$ day zooplankton production throughout the entire water column. This is closer to the estimated full water column zooplankton production for off-vent regions in the current study. If surface primary production were the only source of food for the water column near Endeavour Ridge, the zooplankton production from the entire water column (integrated from 0 to $2000 \mathrm{~m}$ depth) results in a mean $\mathrm{Z}$ ratio $>0.25$. As our estimate is conservative, the $\mathrm{Z}$ ratio could potentially be much higher.

Our results imply that a significant source of energy, other than surface primary production, is fuelling zooplankton growth in the Endeavour Ridge region and that zooplankton production is elevated in the upper $400 \mathrm{~m}$ of the water column, and even more so below $800 \mathrm{~m}$ depth. The only other source of organic input of any significance is seafloor hydrothermal venting. We find that hydrothermal venting could double or triple zooplankton production in the vicinity of the Endeavour vent fields. Previous studies (Burd and Thomson, 1994) indicate that zooplankton aggregation and extraordinary feeding on vent-derived particulates above vent plumes, observed migration of these layers throughout the water column, and enhanced upward flux of zooplankton lipids (in the form of eggs and larvae) from the epiplume zooplankton to the upper ocean (Cowen et al., 2001; Wakeham et al., 2001) provide a mechanism for this enhanced secondary production near Endeavour Ridge.

\subsection{Implications for higher trophic level production}

Our findings show that zooplankton predators in the water column (fish, chaetognaths, and other crustacea such as Mysids) have a higher biomass near venting regions than in the open northeast Pacific. This supports our hypothesis that biomass enhancement from venting is being 
propagated up the food chain. Burd and Thomson (2000) also showed that predaceous jellyfish tend to be enhanced in the deep water column near venting regions. Any enhanced biomass is likely to attract larger predaceous species, notably fish. A lack of acoustic or net data outside the summer season near the vents prevents us from providing biomass and production projections for the rest of the year. It is hoped that more permanent moored acoustic arrays near the Endeavour vents (Fisheries and Oceans Canada and Ocean Networks Canada) will shed light on this issue.

The hypothesis that baleen-whales feeding in the upper ocean may be concentrated in regions of hydrothermal venting (see Weirathmueller et al., 2011) is extremely difficult to prove because of the wide ranging territories of these animals and the limitation of their diving to the upper part of the ocean. It appears that secondary production is higher in summer near the vents than off-axis, and this may be attracting larger consumers, even possibly whales. Energetically, it would make more sense in the summer months for migrant whales to follow drifting surface swarms of euphausiids and other organisms than to concentrate on regions of overall higher secondary production. However, outside the summer season, any whales still feeding in the region would benefit from higher general upper-ocean secondary productivity likely to occur near venting areas. Based on moored seismic array data, Soule and Wilcock (2013) have suggested that some of the fin whales found near Endeavour Ridge do not migrate south in the fall. In addition, the highest concentration of fin whale vocalizations near the ridge is observed in the winter months (Wilcock et al., 2009; Weirathmueller et al., 2011). Acoustic tracking of whale calls through the Endeavour Ridge seismic network (Wilcock et al., 2009; Wilcock, 2012) indicates that observed data gaps of tens of minutes when the whales stop vocalizing occur preferentially above the ridge. Since there is evidence that fin whales stop vocalizing while feeding (Watkins et al., 1987), these short intervals when tracked whales become quiet may 
provide a test of the hypothesis that fin whales feed on enhanced zooplankton concentrations above the hydrothermal vents.

\section{Dedication and Acknowledgements}

This paper is dedicated to the memory of Dr. Peter Rona, who was one of the first experts in marine acoustics to question our original research relating the structure of backscatter intensity profiles over Endeavour Ridge to variations in macro-zooplankton biomass concentration (Thomson et al., 1989, 1990). It was the "Comment" by Palmer and Rona (1990) that forced us to design, build and deploy the deep towed Tucker trawl-ADCP-CTD-Optical package that eventually confirmed our initial findings. The bioacoustics data we present in this publication are the direct result of Peter's fair and objective skepticism, for which we are forever grateful.

Many people contributed to the data and results presented in this study, including Val Macdonald, Les Spearing, Tamás Juhász, David Spear, Steve Mihály, George Chase (deceased), Reg Bigham and John Love. We also thank the officers and crews of the C.C.C.S. John P. Tully and C.F.A.V. Endeavour for their support and dedication during the long instrument tows. Lastly, we thank Professor Richard Lutz for his guidance and for giving us the opportunity to contribute to this volume. This work was partly supported by funds provided by the Office of Naval Research (ONR) Award Number N00014-08-1-0523 to Professor William S. D. Wilcock of the University of Washington. 


\section{References}

Atkinson, A., Ward, P., Hunt, B., Pakhomov, E., Hosie, G., 2012. An overview of southern ocean zooplankton data: Abundance, biomass, feeding and functional relationships. CCAMLR Science $19,171-218$

Baker, E.T., Massoth, G.J., Feely, R.E., Embley, R.W., Thomson, R.E., Burd, B.J., 1995. Hydrothermal vent plumes from the CoAxial seafloor eruption site, Juan de Fuca Ridge. Geophys. Res. Lett. 22, 147-150

Batchelder, H., 1985. Seasonal abundance, vertical distribution, and life history of Metridia pacifica (Copepoda: Calanoida) in the oceanic subarctic Pacific. Deep-Sea Res. 32, 949-964.

Brodeur, R. Frost, B., Hare, S., Francis, R., Ingaham, J., 1996. Interannual variations in zooplankton biomass in the Gulf of Alaska and covariation with California Current zooplankton biomass. CalCOFI Rep. 37:80-99.

Brodeur, R., Ware, D., 1992. Long-term variability in zooplankton biomass in the subarctic Pacific Ocean. Fisheries Oceanography 1, 32-38.

Burd, B.J., Thomson, R.E., Jamieson, G.S., 1992. Composition of a deep scattering layer overlying a mid-ocean ridge hydrothermal plume. Mar. Biol. 113, 517-526. 
Burd, B.J., Thomson, R.E., 1993. Flow volume calculations based on three-dimensional current and net-orientation data. Deep-Sea Res. 40, 1141-1153.

Burd, B.J., Thomson, R.E., 1994. Hydrothermal venting at Endeavour Ridge: Effect on zooplankton biomass throughout the water column. Deep-Sea Res. 41, 1407-1423.

Burd, B.J., Thomson, R.E., 1995. Distribution of zooplankton associated with the Endeavour Ridge hydrothermal plume. J. Plank. Res. 17, 965-997.

Burd, B.J., Thomson, R.E., 2000. Distribution and relative importance of jellyfish in a region of hydrothermal venting. Deep-Sea Res. I 47, 1703-1721.

Burd, B.J., Thomson, R.E., Calvert, S.E., 2002. Isotopic composition of hydrothermal epiplume zooplankton: Evidence of enhanced carbon recycling in the water column. Deep-Sea Res. I 49, 1877-1900.

Burd, B.J., Thomson, R.E., 2012. Estimating zooplankton biomass distribution in the water column near the Endeavour Segment of Juan de Fuca Ridge using acoustic backscatter and concurrently towed nets. Oceanography 25, 269-276.

Cowen, J., Bertram, M., Wakeham, S., Thomson, R., Lavelle, J., Baker, E., Feely, R., 2001. Ascending and descending particle flux from hydrothermal plumes at Endeavour segment, Juan de Fuca Ridge. Deep-Sea Res. I 48, 1092-1120. 
Dagg, M., 1993. Grazing by the copepod community does not control phytoplankton production in the subarctic Pacific Ocean. Prog. Oceanogr. 32, 163-183.

Fukuda, J. A., Yamaguchi, T., Matsuno K., Imai, I., 2012. Interannual and latitudinal changes in zooplankton abundance, biomass and size composition along a central North Pacific transect during summer: analyses with an Optical Plankton Counter. Plankton Benthos Res. 7, 64-74.

Goldblatt, R., Mackas, D., Lewis, A. 1999., Mesozooplankton community characteristics in the NE subarctic Pacific. Deep-Sea Res. II 46, 2619-1644.

Hamme, R. C., Webley, P.W., Crawford, W.R., DeGrandpre, M., Emerson, S., Eriksen, C., Giesbrecht, K., Gower, J., Kavanaugh, M., Pena, M.A., Sabine, C., Batten, S., Coogan, L., Grundle, D., Lockwood, D., 2010. Volcanic ash fuels anomalous plankton bloom in subarctic northeast Pacific, Geophys. Res. Lett. 37, L19604, doi:10.1029/2010GL044629.

Huo, Y., Sun, S., Zhang, F., Wang, M., Li, C., Yang, Bo., 2012. Biomass and estimated production properties of size-fractionated zooplankton in the Yellow Sea, China. J. Mar. Sys. 94, $1-8$.

Ikeda, T., Motoda, S., 1978. Estimated zooplankton production and their ammonia excretion in the Kuroshio and adjacent seas. Fishery Bulletin 76, No.2, 357-367. 
Kelley, D., Carbotte, S., Caress, D., Clague, D., Delaney, J., Gill, J., Hadaway, H., Holden, J., Hooft, E., Kellogg, J., Lilley, M., Stoermer, M., Toomey, D., Weekly, R. Wilcock, W., 2012. Endeavour Segment of Juan de Fuca Ridge: One of the most remarkable places on earth. Oceanography 25, March 2012 Special issue on Ridge 2000 Program Research, 44-61.

Kokari, T., Ideda, T., 2001a. Life cycle of Neocalanus flemingeri (Crustacea: Copepoda) in the Oyashio region, western subarctic Pacific, with notes on its regional variations. Mar. Ecol. Prog. Ser. Vol. 209, 243-255.

Kobari, T., Ikeda, T., 2001b. Ontogenetic vertical migration and life cycle of Neocalanus plumchrus (Crustacea: Copepoda) in the Oyashio region, with notes on regional variations in body sizes. J. Plank. Res. 23, 287-302.

Landry, M. and Fagerness, V., 1988. Behavioral and morphological influences on predatory interactions among marine copepods. Bull. Mar. Sci. 453, 509-529.

Lavelle, J.W., Di Iorio, D., Rona, P. 2013. A turbulent convection model with an observational context for a deep-sea hydrothermal plume in a time-variable cross flow. J. Geophys. Res. 118, 6145-6160.

Mackas, D.L., 1995. Interannual variability of the zooplankton community off southern Vancouver Island, In Beamish, R.J. (Ed.), Climate change and northern fish populations. Can. Spec. Pub. Fish. Aquat. Sci. 121, pp. 603-615. 
Mackas, D.L., Batten, S., Trudel, M., 2007. Effects on zooplankton of a warmer ocean: Recent evidence from the Northeast Pacific. Progr. Oceanogr. 75, 223-252.

Mackas, D., Beaugrand, G., 2010. Comparisons of zooplankton time series. J. Mar. Syst. 79, 286304.

Mackas, D. Sefton, H., Miller, C., Raich, A., 1993. Vertical habitat partitioning by large calanoid copepods in the oceanic subarctic Pacific during spring. Prog. Oceanogr. 32, 259-294.

Madin, L.P., Horgan, E.F., Steinberg, D.K., 2001. Zooplankton at the Bermuda Atlantic Timeseries Study (BATS) station: diel, seasonal and interannual variation in biomass, 1994-1998. Deep-Sea Research II 48, 2063-2082.

Miller, C.B., Frost, B.W., Batchelder, H.P., Clemons, M.J. and Conway, R.E., 1984. Life histories of large, grazing copepods in the subarctic ocean gyre: Neocalanus plumchrus, Neocalanus cristatus, and Eucalanus bungii in the northeast Pacific. Prog. Oceanogr., 13, 201243.

Miller, C., Clemons, M., 1988. Revised life history analysis for large grazing copepods in the subarctic Pacific Ocean. Prog. Oceanogr. 20, 393-313. 
Nagasawa, K., 2000a. Long-term changes in the climate and ocean environment in the Okhotsk Sea and western North Pacific and abundance and body weight of East Sakhalin pink salmon (Oncorhynchus gorbuscha). N. Pac. Anadr. Fish Comm. Bull. 2, 203-211.

Nagasawa, K., 2000b. Winter zooplankton biomass in the subarctic North Pacific, with a discussion on the overwintering survival strategy of Pacific salmon (Oncorhynchus spp.). N. Pac. Anadr. Fish Comm. Bull. 2, 21-32.

Palmer, D. R., Rona, P. A., 1990. Comment on “Acoustic Doppler Current Profiler Observations of a Mid-Ocean Ridge Hydrothermal Plume” by R. E. Thomson et al., J. Geophys. Res. 95, 54095412.

Perry, I., Welch, D., Harrison, P., Mackas, D., Denman, K., 1998. Epipelagic fish production in the open Subarctic Pacific: bottom-up or self-regulating control? PICES 6, January 1998, 26-32.

Platt, T., Sathyendranath, S., 1988. Oceanic Primary Production: Estimation by Remote Sensing at Local and Regional Scales. Science 241, 1613-1620.

Runge, J.A., Roff, J.C., 2000. The measurement of growth and reproductive rates, In Harris, R.P., Wiebe., P.H., Lenz, J., Skjoldal, H.R., Huntley, M. (Eds.), ICES Zooplankton Methodology Manual. Academic Press, London, pp. 401-407. 
Sabates, A., Gili, J.M., Pages, E., 1989. Relationship between zooplankton distribution, geographic characteristics and hydrographic patterns off the Catalan coast (Western Mediterranean). Marine Biology 103, 153-159.

Soule, D. C. and Wilcock, W. S. D., 2013. Fin whale tracks recorded by a seismic network on the Juan de Fuca Ridge, Northeast Pacific Ocean. J. Acoust. Soc. Am. 133, 1751-1761, doi.org/10.1121/1.4774275.

Stanton, T., Wiebe, P., Chu, D., Benfield, M., Scanlon, L., Martin, L., Eastwood, R., 1994. On acoustic estimates of zooplankton biomass. ICES J. Mar. Sci. 51, 505-512.

Steinberg, D., Carlson, C., Bates, N., Goldthwait, S., Madine, L., Michaels, A., 2000.

Zooplankton vertical migration and the active transport of dissolved organic and inorganic carbon in the Sargasso Sea. Deep Sea Res. I 47, 137-158.

Stock, C., Dunne, J., 2010. Controls on the ratio of mesozooplankton production to primary production in marine ecosystems. Deep-Sea Research I 57, 95-112.

Sugimoto, T., Tadokoro, K., 1997. Interannual interdecadal variations in zooplankton biomass, chlorophyll concentration and physical environment in the subarctic Pacific and Bering Sea. Fisheries Oceanogr. 6, 74-93.

Terazaki, M., Miller, C., 1986. Life history and vertical distribution of pelagic chaetognaths at Ocean Station P in the subarctic Pacific. Deep-Sea Res. 33, 323-337. 
Thomson, R.E., Gordon, R.L., Dymond, J., 1989. Acoustic Doppler current profiler observations of a mid-ocean ridge hydrothermal plume. J. Geophys. Res. 94, 4709-4720.

Thomson, R.E., Gordon, R.L., Gast, J.A., 1990. Reply to Comment on "Acoustic Doppler Current Profiler Observations of a Mid-Ocean Ridge Plume" by D.R. Palmer and P.A. Rona. J. Geophys. Res. 95, 5413-5415.

Thomson, R.E., Gordon, R.L. Dolling, A.G., 1991. An intense acoustic scattering layer at the top of a mid-ocean ridge hydrothermal plume. J. Geophys. Res. 36, 4839-4844.

Thomson, R., Delaney, J., McDuff, R., Janecky, D., McClain, J., 1992. Physical characteristics of the Endeavour Ridge hydrothermal plume during July 1988. J. Geophys. Res. 94, 4709-4720.

Thomson, R.E., Davis, E.E., Burd, B.J., 1995. Hydrothermal venting and geothermal heating in Cascadia Basin. J. Geophys. Res. 100, 6121-6141.

Thomson, R.E., Mihály, S.F., Rabinovich, A.B., McDuff, R.E., Veirs, S.R., Stahr, F.R., 2003. Constrained circulation at Endeavour Ridge facilitates colonisation by vent larvae. Nature 424, 545-549. doi:10.1038/nature01824. 
Thomson, R.E., Subbotina, M., Anisimov, M., 2005. Numerical simulation of hydrothermal ventinduced circulation at Endeavour Ridge. J. Geophys Res. 110. doi:10.1029/2004JC002337, C01004 1-14.

Thomson, R.E., Fine, I.V., 2009. A diagnostic model for mixed-layer depth estimation with application to Ocean Station P in the northeast Pacific. J. Phys. Oceanogr. 39, 1399-1415.

Thomson, R.E., Subbotina, M., Anisimov, M., 2009. Numerical simulation of mean currents and water property anomalies at Endeavour Ridge: Hydrothermal versus topographic forcing. J. Geophys. Res. 114, C09020. doi:10.1029/2008JC005249.

Tunnicliffe, W., Embley, R.W., Holden, J.F., Butterfield, D.A., Massoth, G.J., Juniper, S.K., 1997. Biological colonization of new hydrothermal vents following an eruption on Juan de Fuca Ridge. Deep-Sea Research I, 44, 1627-1644.

Tunnicliffe, V., Botros, M., de Burgh, M., Dinet, A., Johnson, P., Juniper, K., McDuff, R., 1986. Hydrothermal vents of Explorer Ridge, northeast Pacific. Deep-Sea Res. A 33, 401-412.

Uye, S-I., Nagano, N., Shimazu, T., 2000. Abundance, Biomass, Production and trophic Roles of Micro- and Net-Zooplankton in Ise Bay, Central Japan, in Winter. Journal of Oceanography 56, 389-398. 
Wakeham, S.G., Cowen, J.P., Burd, B.J., Thomson, R.E., 2001. Lipid-rich ascending particles from the hydrothermal plume at Endeavour Segment, Juan de Fuca Ridge. Geo. et Cosmo. Acta 65, 923-939.

Watkins, W. A., Tyack, P., Moore, K.A., 1987. The 20-Hz signals of finback whales (Balaenopteraphysalus). J. Acoust. Soc. Am. 82, 1901-1912.

Weirathmueller, M.J., Soule, D.C. and Wilcock, W.S., 2011. Variations in the number of fin whale calls recorded at different locations in the Northeast Pacific Ocean. J. Acoust. Soc. Am. $129,2637$.

Wilcock, W. S. D., 2012. Tracking fin whales in the northeast Pacific Ocean with a seafloor seismic network. J. Acoust. Soc. Am., 132, doi.org/10.1121/1.4747017.

Wilcock, W. S. D., Soule, D.C., Thomson, R.E., 2009. Tracking fin and blue whales above the Juan de Fuca Ridge with a local seafloor network. J. Acoust. Soc. Am., 125, 2588.

Wong, C., Whitney, F., Iseki, K., Page, J., Zeng, J., 1995. Analysis of trends in primary productivity and chlorophyll-a over two decades at Ocean Station $\mathrm{P}\left(50^{\circ} \mathrm{N}, 145^{\circ} \mathrm{W}\right)$ in the Subarctic northeast Pacific Ocean, In Beamish, R.J. (Ed.) Climate change and northern fish populations. Can. Spec. Publ. Fish. Aquat. Sci. 121, pp. 107-117. 
Young, J., Bradford, W., Lamb, T., Lyne, V., 1996. Biomass of zooplankton and micronekton in the southern Bluefin tuna fishing grounds off eastern Tasmania, Australia. Mar. Ecol. Progr. Ser. $138,1-14$.

\section{Figure Captions}

Figure 1. Locations of net tows used in the study. The central cluster denotes the location of the main Endeavour Ridge venting segment, which runs NNE-SSW through the central cluster of tows. Black dots represent start locations, while red dots indicate end location for tows. The insert shows the location of the Endeavour Segment of Juan de Fuca Ridge and principal plate boundaries and faults in the northeast Pacific Ocean.

Figure 2. Schematic of the towed sampling frame used in the study. The 7-net package is towed to the right from a slowing moving ship; a rosette mechanism is used to trigger the individual nets. The first net is kept open during the decent, and six individual net samples are collected on the up-tow. The Teledyne-RDI acoustic Doppler current profiler (ADCP) and Guildline conductivity-temperature-depth (CTD) probe and Seatech transmissometer were mounted just below the net frame (for further details, see Burd and Thomson, 1993, 1994).

Figure 3. (a) Vertically integrated total dry-weight biomass (total biomass in a $1 \mathrm{~m}^{2}$ vertical column integrated from 0 to $2000 \mathrm{~m}$ depth, thus having units of $\mathrm{mg} / 2000 \mathrm{~m}^{3}$ ) for all nets in each tow, as functions of mean distance from the main Endeavour vent fields; and (b) secondary biomass production (0-2000 $\mathrm{m}$ depth) estimated for each tow. The diagonal lines denote the linear least-squares regressional fits to the data distributions. 
Figure 4. Biomass for the different faunal groups relative to the total biomass shown for all net tows, with best linear least-squares regression fit. Note that the biomass is shown as total per tow for visual clarity, and not corrected for net volume. Correlations were calculated for individual net samples ( $\mathrm{N}=197$; see Table 1), as described in Results.

Figure 5. Total depth-integrated biomass $\left(\mathrm{mg} / \mathrm{m}^{2}\right)$ for each depth range shown, along with total integrated biomass for the entire water column (0 to $2000 \mathrm{~m}$ depth) for ACDP bin 1 estimated from backscatter intensity based on the model in Burd and Thomson (2012). Values are estimated from the forward-pointing beam 3 of the ADCP.

Figure 6. Log-log relationship between dry-weight biomass and production for all net samples. The relationship was significant at $\mathrm{p}<0.01$ with a linear regression for production, with Production $=0.0041 \times(\text { biomass })^{1.0021}$. 


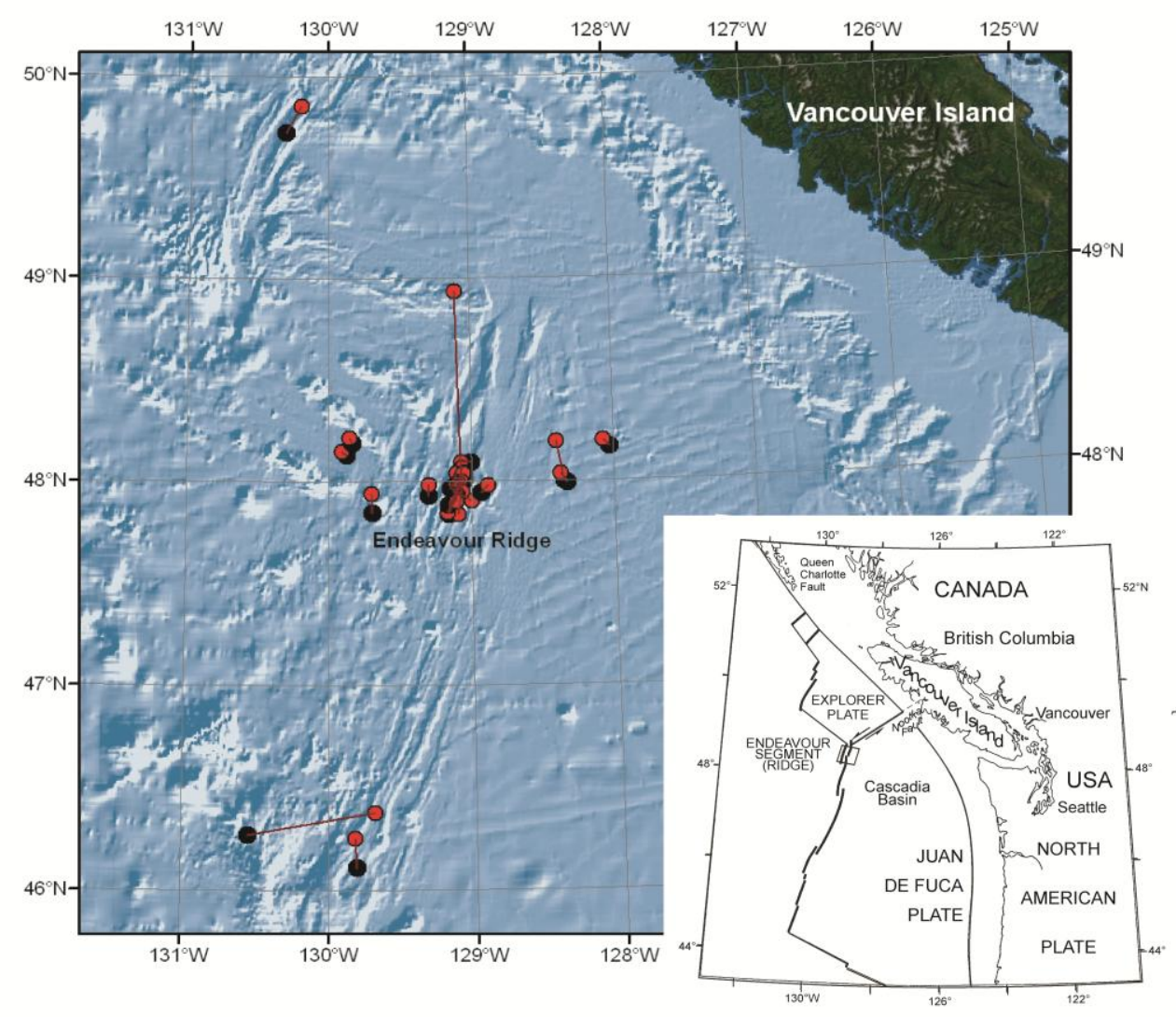

Figure 1. Locations of net tows used in the study. The central cluster denotes the location of the main Endeavour Ridge venting segment. Black dots represent start locations while red dots indicate end location for tows. The insert shows the location of the Endeavour Segment of Juan de Fuca Ridge and principal plate boundaries and faults in the northeast Pacific Ocean. 


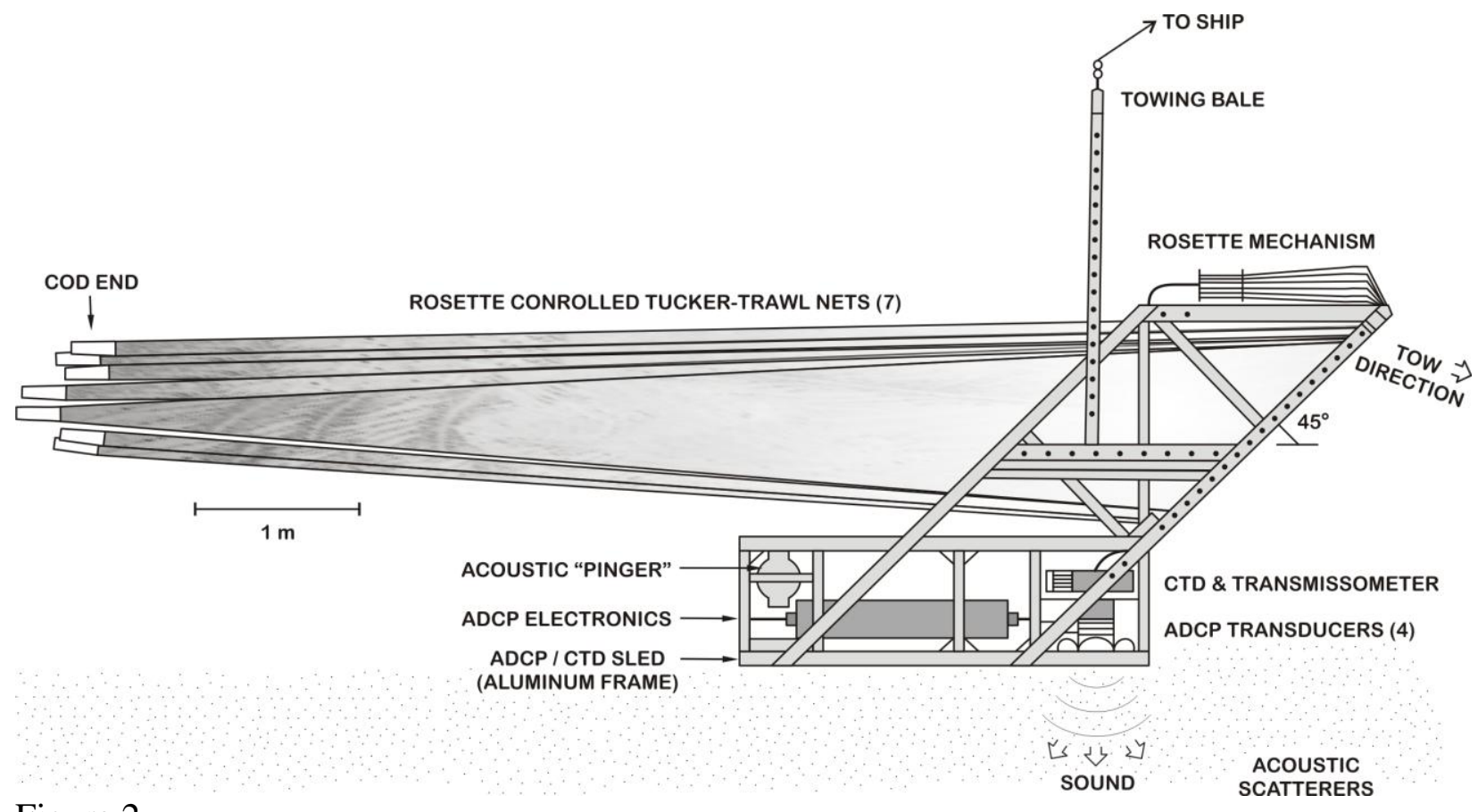

Figure 2 

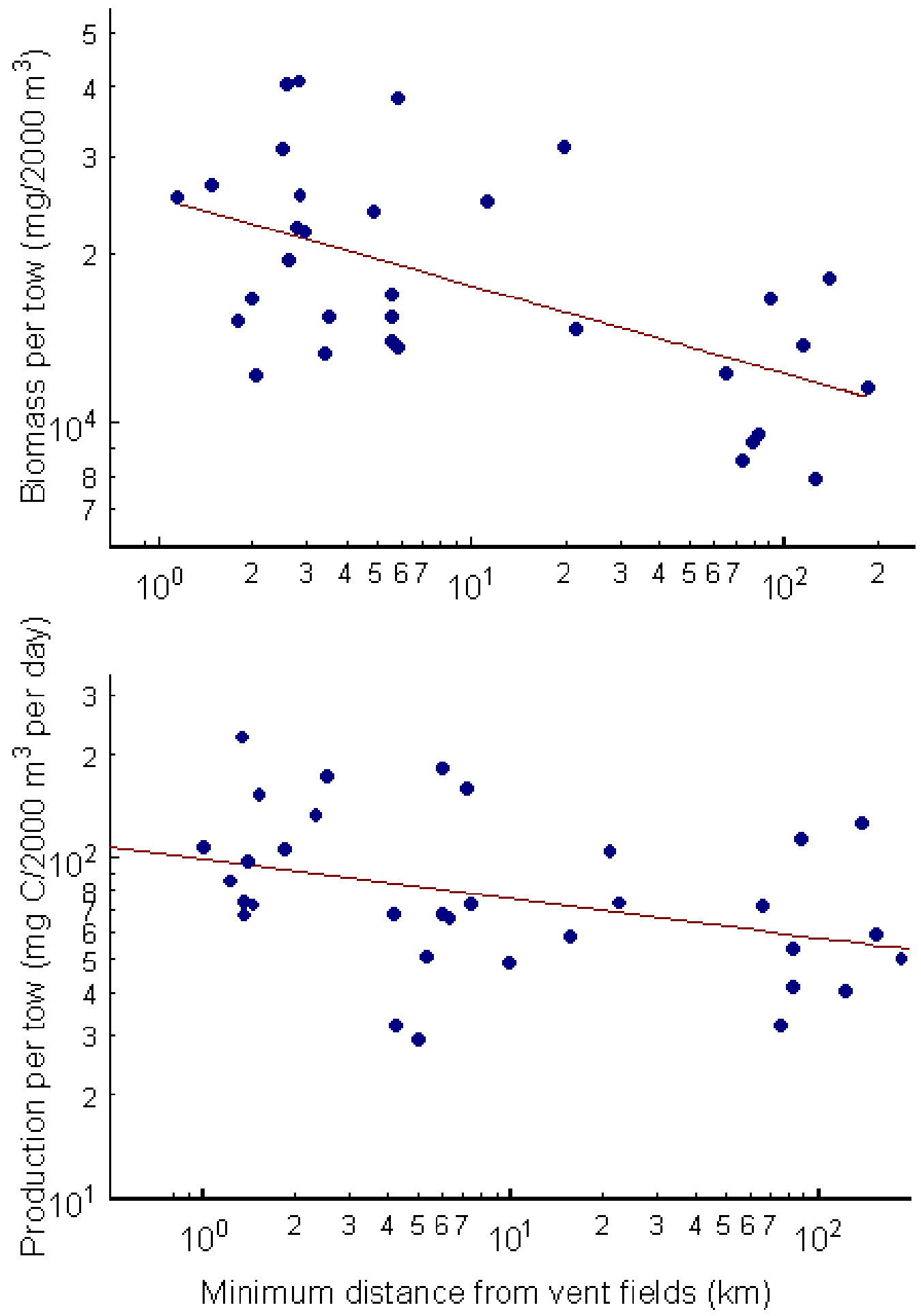

Figure 3 


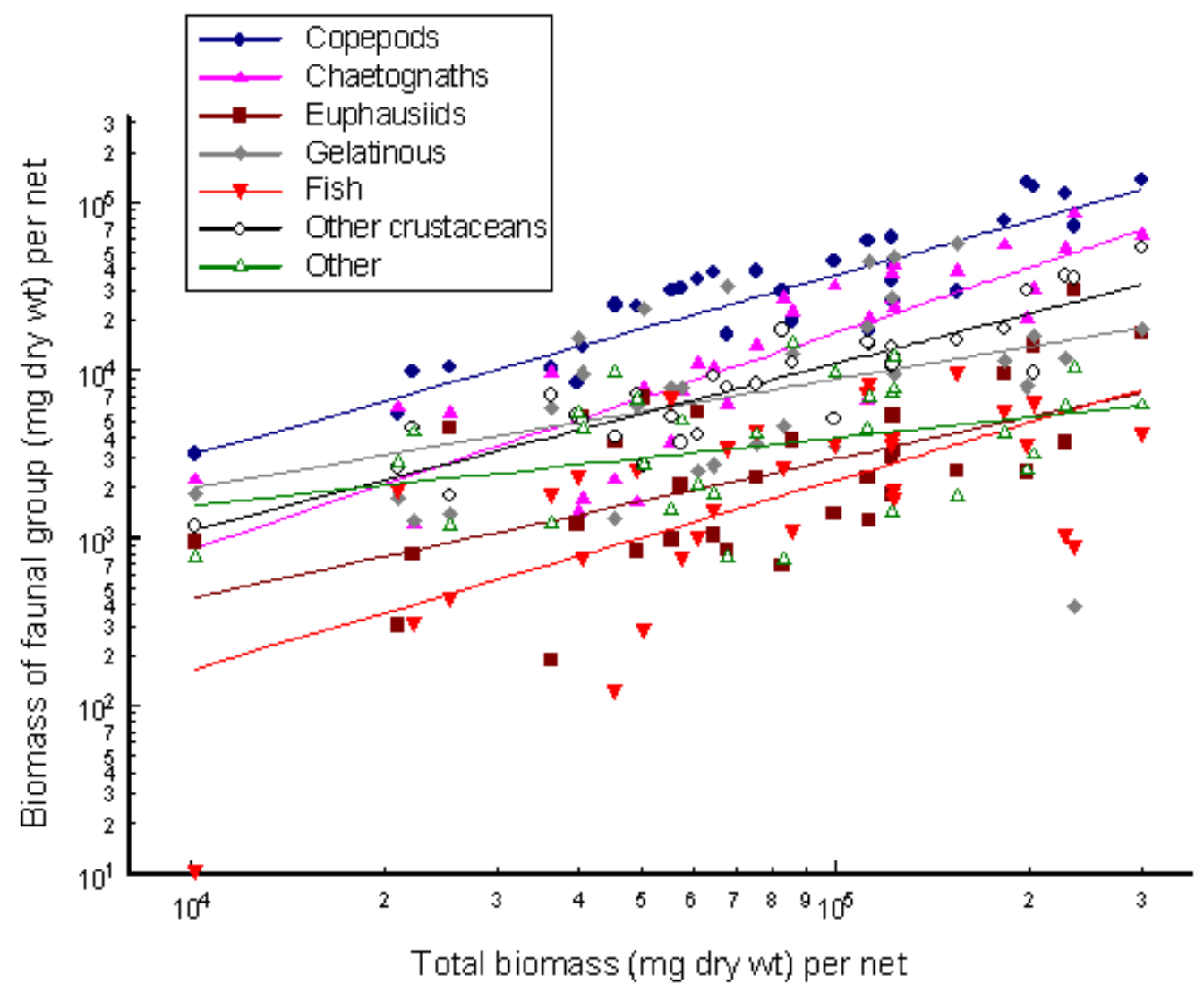

Figure 4 


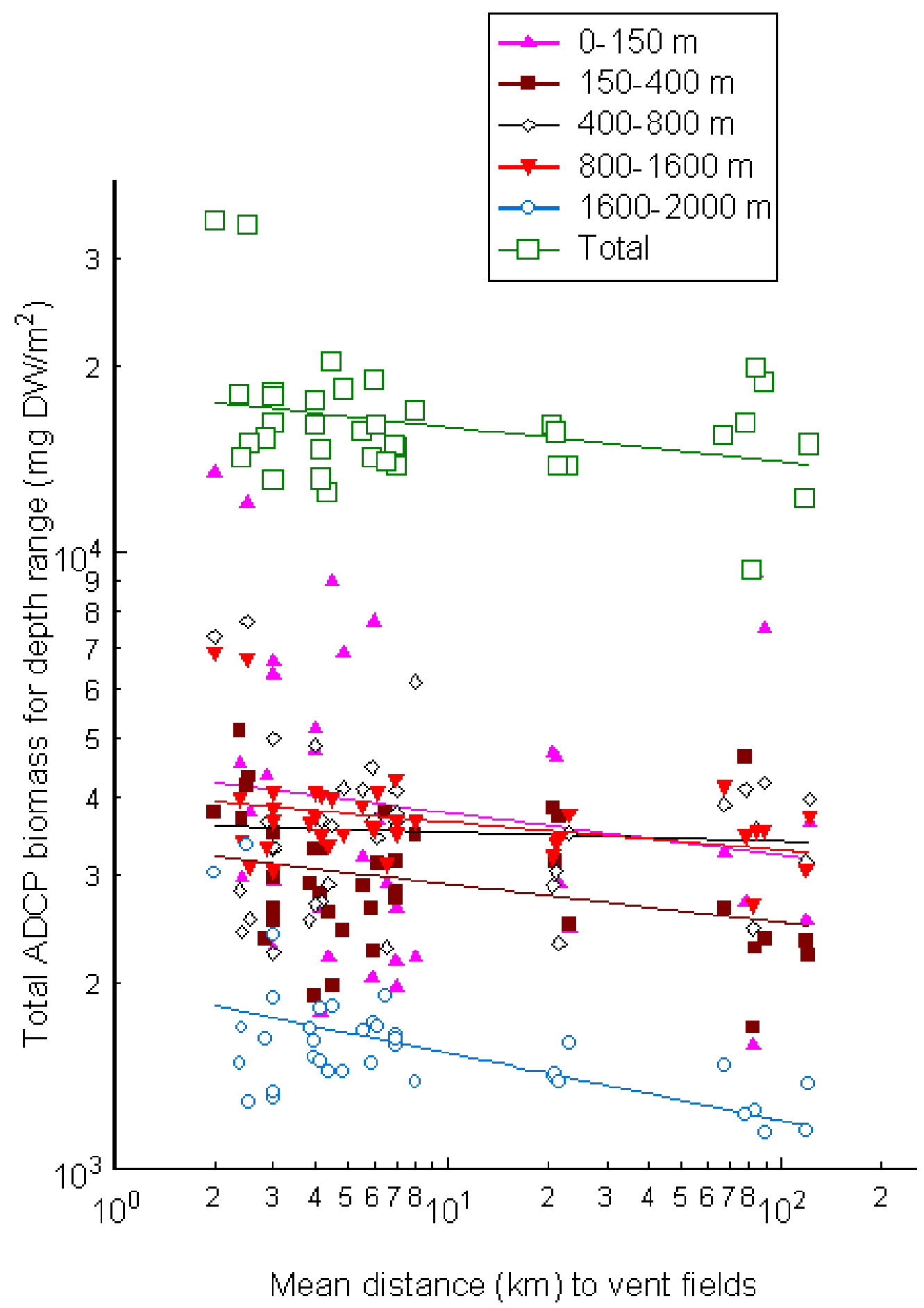

Figure 5 


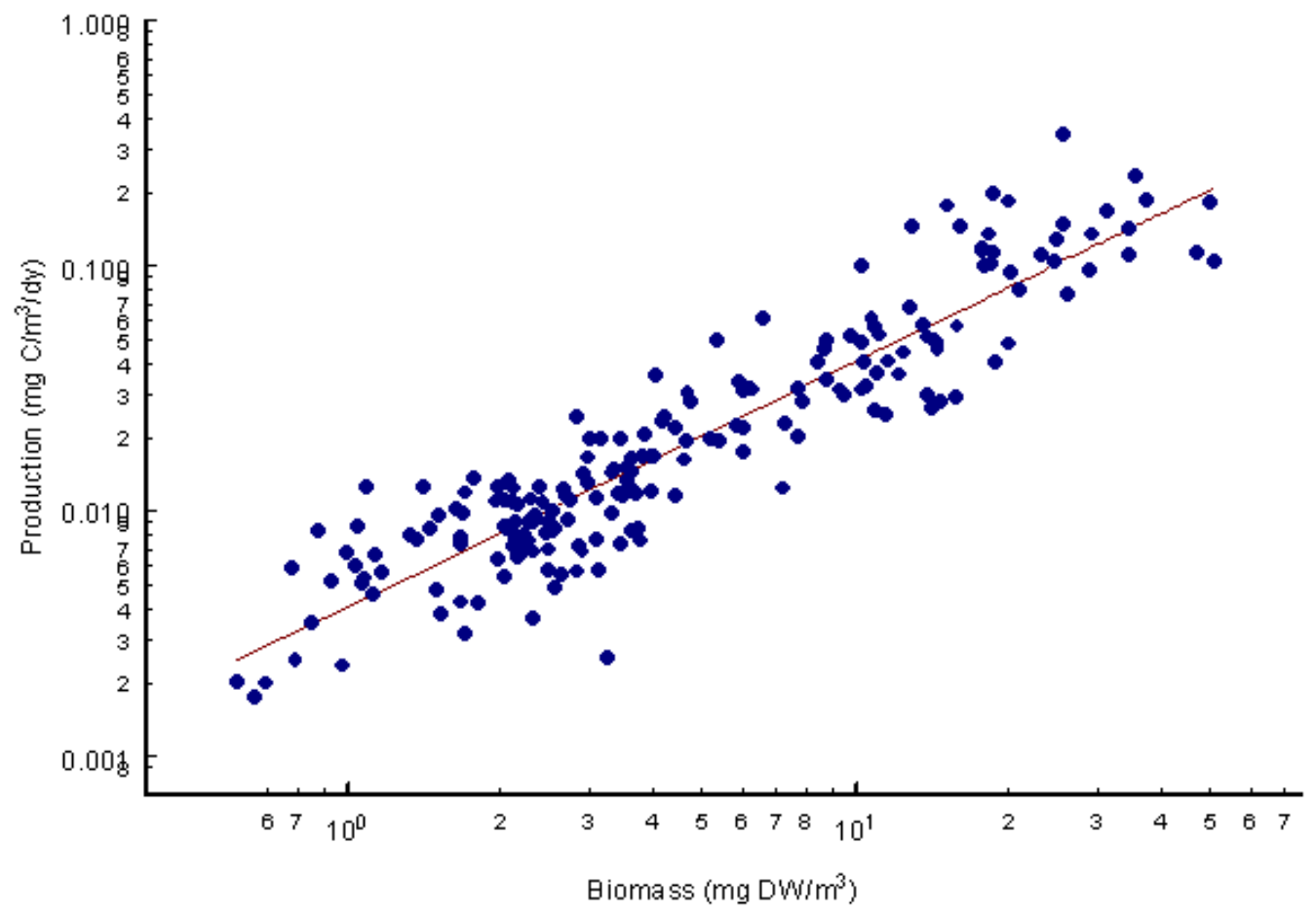

Figure 6 
Table 1. Mean percent of total biomass for the major biological groups from all net samples $(\mathrm{N}=197)$ for all six summer sampling periods. SD denotes the standard deviation about the mean value (\%). The correlation coefficient ( $\mathrm{r}$ ) and probability (p) are given for the comparison of each faunal group biomass with total net sample biomass.

\begin{tabular}{|l|c|c|c|c|}
\hline Faunal Group & Mean (\%) & SD (\%) & Correlation, $r$ & $p$ \\
\hline Copepods & 42.9 & 15 & 0.89 & $<0.01$ \\
\hline Chaetognaths & 16.4 & 11 & 0.86 & $<0.01$ \\
\hline Euphausiids & 3.0 & 5 & 0.66 & $<0.01$ \\
\hline Gelatinous* & 15.2 & 13 & 0.27 & 0.14 \\
\hline fish & 4.9 & 6 & 0.38 & $<0.05$ \\
\hline Other crustacea & 12.2 & 8 & 0.88 & $<0.01$ \\
\hline other & 6.4 & 7 & 0.27 & 0.14 \\
\hline
\end{tabular}

* Note that this was an arbitrary grouping of several phyla with gelatinous body types 
Table 2. Literature comparisons of upper ocean meso-zooplankton biomass measurements with results from the current study. WW= wet weight; DW=Dry weight

\begin{tabular}{|c|c|c|c|c|c|}
\hline Location & Reference & Time of year & depth & $\begin{array}{l}\text { Biomass (original } \\
\text { units) }\end{array}$ & $\begin{array}{l}\text { Biomass (DW } \\
\mathrm{mg} / \mathrm{m}^{3} \text { ) }\end{array}$ \\
\hline ER NE Pacific from ADCP & Burd and Thomson (this paper) & summer (July/August) & $0-150 \mathrm{~m}$ & $11-90 \mathrm{mg} \mathrm{DW} / \mathrm{m}^{3}$ & $11-90$ \\
\hline ER NE Pacific from nets & Burd and Thomson (this paper)++ & summer (July/August) & $0-400 \mathrm{~m}$ & 9-50 mg DW/m $/ \mathrm{m}^{3}$ & $9-50$ \\
\hline ER NE Pacific from ADCP & Burd and Thomson (this paper) & summer (July/August) & $0-400 \mathrm{~m}$ & $7-43 \mathrm{mg} \mathrm{DW} / \mathrm{m}^{3}$ & $7-43$ \\
\hline ER NE Pacific from nets & Burd and Thomson (this paper) & summer (July/August) & $0-2000 \mathrm{~m}$ & 4-21.5 mg DW/m $\mathrm{m}^{3}$ & 4-20.5 \\
\hline ER NE Pacific from ADCP & Burd and Thomson (this paper) & summer (July/August) & $0-2000 \mathrm{~m}$ & 6-17.5 mg DW/m $\mathrm{m}^{3}$ & $6-17.5$ \\
\hline Shelf/slope Vancouver Island) 1985-1992 & Mackas 1995 & summer (May/June) & $0-250 \mathrm{~m}$ & $6.8 \mathrm{~g} / \mathrm{m}^{2} \mathrm{DW}$ & 27 \\
\hline Ocean Station P, NE Pacific (mean 1956-80) & $\begin{array}{l}\text { Brodeur and Ware 1992, Sugimoto and } \\
\text { Tadokoro } 1997\end{array}$ & summer (May/June) & $0-150 \mathrm{~m}$ & $\begin{array}{l}200-300 \mathrm{~g} / 1000 \mathrm{~m}^{3} \\
\mathrm{WW}^{* *}\end{array}$ & $26-48$ \\
\hline Ocean Station P (1995-97) & Goldblatt et al. 1999 & summer (May/June) & $0-150 \mathrm{~m}$ & $250-500 \mathrm{mg} / \mathrm{m}^{3} \mathrm{WW}$ & $32.5-65$ \\
\hline Ocean Station P and N Pacific (mean to 1989) & Brodeur et al. 1996 & summer (May/June) & $0-150 \mathrm{~m}$ & $120-250 \mathrm{~g} / 1000 \mathrm{~m}^{3} \mathrm{WW}$ & $15.6-32.5$ \\
\hline Central and western Pacific & Nagasawa 2000a & summer (May/June) & $0-150 \mathrm{~m}$ & $200-300 \mathrm{mg} / \mathrm{m}^{3} \mathrm{WW}$ & $26-48$ \\
\hline Central and western Pacific & Nagasawa 2000b & winter (Nov-Jan) & $0-150 \mathrm{~m}$ & $1-125 \mathrm{mg} / \mathrm{m}^{3} \mathrm{WW}$ & $3.25++$ \\
\hline 180o, 31-51oN 1982-2000 N Pacific & Fukuda et al. 2012 & summer (June) & $0-150 \mathrm{~m}$ & $7-13 \mathrm{mg} / \mathrm{m}^{3} \mathrm{DW}$ & $7-13+$ \\
\hline Japan offshore & Uye et al. 2000 & winter (February) & $0-150 \mathrm{~m}$ & $4.5 \mathrm{mg} \mathrm{C} / \mathrm{m}^{3 *}$ & 13.5 \\
\hline Ross Sea & Stock and Dunne 2010 & summer (May/June) & $0-200 \mathrm{~m}$ & $0.5-0.7 \mathrm{~g} \mathrm{C} / \mathrm{m}^{2}$ & $7.5-10.5$ \\
\hline Yellow Sea & Huo et al. 2012 & summer (May/June) & $<100 \mathrm{~m}$ & $32 \mathrm{mg} \mathrm{DW} / \mathrm{m}^{3}$ & 32 \\
\hline Tasmanian Sea & Young et al. 1996 & winter (May-June) & $0-350 \mathrm{~m}$ & $2-4 \mathrm{~g} \mathrm{DW} / 1000 \mathrm{~m}^{3}$ & $2-4$ \\
\hline W Mediterranean & Sabates et al., 1989 & spring (April-May) & $0-200 \mathrm{~m}$ & $48-60 \mathrm{mg} / \mathrm{m}^{3} \mathrm{WW}$ & $6.2-7.8$ \\
\hline W Mediterranean & Sabates et al., 1989 & summer (June/July) & $0-200 \mathrm{~m}$ & $10-12 \mathrm{mg} / \mathrm{m}^{3} \mathrm{WW}$ & 1.3-1.6 \\
\hline Bermuda BATS Atlantic & Madin et al. 2001 & Full year 4 yrs & $0-200 \mathrm{~m}$ & 41.8-65.9 mg DW/m² & $2.1-3.3$ \\
\hline
\end{tabular}

*assume $3 \times$ organic carbon to DW conversion

** assume 0.13 conversion WW to DW for mixed crust/gelatinous (see in Perry et al., 1998)

+ closest station to $48^{\circ} \mathrm{W}$

++ Note that nets were towed from a minimum of $400 \mathrm{~m}$ depth to the surface and are therefore conservative estimates for the depth range $0-250 \mathrm{~m}$. 